\title{
TACKLING THE PROPENSITY TOWARDS UNDECLARED WORK: SOME POLICY LESSONS FROM CROATIA
}

Colin C. Williams, Josip Franic *

Abstract

The aim of this paper is to evaluate contrasting policy approaches towards undeclared work. To do so, evidence is reported from 1,000 face-to-face interviews conducted in Croatia during 2013. Logistic regression analysis reveals no association between participation in undeclared work and the perceived level of penalties and risk of detection, but a strong association between participation in undeclared work and the level of tax morality. It thus confirms recent calls for the conventional direct controls approach, which seeks to deter engagement in undeclared work by increasing the penalties and risk of detection, to be replaced by an indirect controls approach which seeks to improve tax morality so as to encourage greater self-regulation and a culture of commitment to compliance. The implications for theory and policy are then discussed.

Keywords: informal sector; tax morale, institutional theory; tax evasion; Croatia; South-East Europe

JEL: $E 26, H 26, J 46,017$

\section{INTRODUCTION}

The aim of this paper is to evaluate various policy approaches that can be used to tackle undeclared work. Although there is a growing understanding of the extent and character of undeclared work in South-Eastern Europe (Baric and Williams 2013, Gaspareniene, Kartasova and Remeikiene 2014; Hudson et al. 2012; Remeikiene, Gasparaeniene and Kartasova 2014; Schneider 2013; Williams, Franic and Dzhekova 2014; Williams et al. 2012, 2013), little attention has been so far paid to evaluating the various policy approaches available for tackling this phenomenon. However, unless effective strategies are developed to tackle the undeclared economy, not only will governments continue to lose public revenue due to its prevalence but the unfair competition faced by legitimate businesses and poorer quality working conditions faced by workers will remain (Andrews, Caldera Sanchez and Johansson 2011; ILO 2014). Tackling the undeclared economy which represents around a quarter of Gross Domestic Product (GDP) in SouthEast Europe is therefore an important task for SouthEast European governments (Schneider and Williams 2013).

To evaluate the various policy approaches available for tackling the undeclared economy, section 2

\section{* Colin C. Williams}

Professor of Public Policy

Management School, University of Sheffield, UK

C.C.Williams@sheffield.ac.uk

\section{Josip Franic}

Marie Curie Research Fellow

Management School, University of Sheffield, UK jfranic1@sheffield.ac.uk 
provides a conceptual framework for understanding the range of policy approaches available and shows how until now in South-Eastern Europe, the focus has been upon using a direct controls approach which seeks to tackle the undeclared economy by increasing the penalties and risk of detection confronting those participating or thinking about participating in undeclared work. Despite recent calls in the scholarly literature for an indirect controls approach which engenders a commitment to compliance, South-East European governments have been slow to consider such an approach. This however is perhaps unsurprising since there have been few evaluations of these contrasting approaches. To begin to fill this gap therefore, section 3 introduces the data and methodology used here to do so, namely a logistic regression analysis of 1,000 face-to-face interviews conducted in 2013 in Croatia. Section 4 then reports the results. Finding no significant association between participation in undeclared work and the perceived level of penalties and risk of detection on the one hand, and a strong association between participation in undeclared work and a commitment to compliance on the other, section 5 discusses the policy implications before section 6 draws some conclusions.

Before commencing nevertheless, undeclared work must be defined. In this paper, and reflecting the consensus in the literature, undeclared work is defined as paid work which is legal in all respects other than it is not declared to the authorities for tax, social security or labour law purposes (Aliyev 2015; Boels 2014; European Commission 2007; OECD 2012; Polese and Rodgers 2011; Williams 2014a,b). If it is not legal in all other respects, it is not part of the undeclared economy. For example, if the goods and/or services exchanged are illegal (e.g., illegal drugs), then this is not part of the undeclared economy but part of the wider criminal economy.

\section{BACKGROUND: POLICY APPROACHES TOWARDS UNDECLARED WORK}

Undeclared work is an extensive and persistent feature across South-East European economies (Schneider 2013; Williams 2014a). This is particularly the case in Croatia where Schneider (2013) estimates that undeclared work in 2013 was equivalent to 28.4 per cent of GDP and Williams (2014a) estimates that the share of employment in the undeclared economy in 2013 was 22.7 per cent. Indeed, Croatia has one of the largest undeclared economies in South-Eastern Europe (Williams, Franic and Dzhekova 2014). Whether one examines the results of direct surveys (Rubić 2013;
Williams 2014a) or the results of indirect measurement methods using proxy indicators (Galić Nagyszombaty 2012; Klarić 2011; Ott 2002; Schneider 2013), a similar finding is revealed. The undeclared economy is equivalent to around a quarter of total GDP and employment in Croatia. As a result, recent years has seen the issue of tackling the undeclared economy rapidly rise up the political agenda in Croatia, with the Ministry of Labour designating 2014 'the year of the fight against undeclared work' (Ministry of Labour and Pensions System 2014).

How, therefore, can the undeclared economy be tackled? To review the possible policy approaches, Table 1 provides a heuristic conceptual framework. This distinguishes between direct and indirect control approaches. Direct control approaches seek to tackle undeclared work by ensuring that benefits of operating in the declared economy outweigh the costs of working in the undeclared economy. This can be accomplished either by using deterrence measures to increase the costs of non-compliance ('sticks') and/or by making the conduct of declared work more beneficial ('carrots'). Indirect control approaches, meanwhile, shift away from using 'sticks' and 'carrots', and instead focus on developing the psychological contract (or what might also be called the social contract) between the state and its citizens so as to encourage a commitment to compliance among citizens and thus greater self-regulation.

Here, each approach is reviewed in turn so as to highlight the measures available for tackling the undeclared economy.

\section{Direct Controls Approach}

The conventional policy approach for tackling undeclared work is to use direct controls. During the early 1970s, Allingham and Sandmo (1972) argued that the non-compliant, such as undeclared workers, are rational economic actors who evade tax when the pay-off is greater than the expected cost of detection and punishment. To deter them therefore, the objective is to change the cost/benefit ratio facing those participating or considering participation in undeclared work (e.g., Hasseldine and Li 1999; Job, Stout and Smith 2007; Richardson and Sawyer 2001). As the OECD (2008: 82) summarize, 'Combating informal employment requires a comprehensive approach to reduce the costs and increase the benefits to business and workers of operating formally'. The most common approach is to increase the actual and perceived risks and costs associated with participation in undeclared work firstly, by raising the perceived 
Table 1 Typology of policy approaches for tackling undeclared work

\begin{tabular}{|c|c|c|}
\hline Approach & Method & Measures \\
\hline \multirow[t]{2}{*}{$\begin{array}{l}\text { Direct controls: } \\
\text { deterrents ("sticks") }\end{array}$} & Improved detection & $\begin{array}{l}\text { Data matching and sharing } \\
\text { Joined up strategy } \\
\text { Joint operations }\end{array}$ \\
\hline & Increased penalties & Increased penalties for evasion \\
\hline \multirow[t]{2}{*}{$\begin{array}{l}\text { Direct controls: } \\
\text { Incentives ("carrots") }\end{array}$} & Preventative & $\begin{array}{l}\text { Simplification of compliance } \\
\text { Direct and indirect tax incentives } \\
\text { Supply chain responsibility } \\
\text { Support and advice }\end{array}$ \\
\hline & Curative & $\begin{array}{l}\text { Supply-side incentives (e.g. society-wide amnesties; vol- } \\
\text { untary disclosure; smoothing transition to legitimization) } \\
\text { Demand-side incentives (e.g. service vouchers; targeted } \\
\text { direct taxes; targeted indirect taxes) }\end{array}$ \\
\hline \multirow[t]{2}{*}{$\begin{array}{l}\text { Indirect controls: } \\
\text { reduce asymmetry } \\
\text { between formal and } \\
\text { informal institutions }\end{array}$} & $\begin{array}{l}\text { Change informal institutions (values, } \\
\text { norms and beliefs) }\end{array}$ & $\begin{array}{l}\text { Tax education } \\
\text { Normative appeals } \\
\text { Education and awareness raising of benefits of declared } \\
\text { work }\end{array}$ \\
\hline & $\begin{array}{l}\text { Change formal institutions (laws, } \\
\text { regulations and codes) }\end{array}$ & $\begin{array}{l}\text { Procedural fairness and justice } \\
\text { Redistributive justice } \\
\text { Wider economic and social developments (e.g., social } \\
\text { protection, equality, growth strategies for quality employ- } \\
\text { ment, entrepreneurship support) }\end{array}$ \\
\hline
\end{tabular}

or actual likelihood of detection and/or secondly, increasing the penalties and sanctions for those caught. This is therefore a 'negative reinforcement' approach; it uses 'sticks' to punish non-compliant ('bad') behavior (Williams 2014b). Indeed, this is the dominant approach used in Croatia (see Baric and Williams 2013; Franic and Williams 2014; Official Gazette 2011; State Inspectorate 2013a,b).

Given that it is increasingly recognized that the goal is not to eradicate undeclared work but rather, to transform it into declared work, another way of using direct controls is to provide incentives ('bribes') to increase the benefits of declared work (Small Business Council 2004). Put another way, rather than punish 'bad' (non-compliant) behaviour, direct controls can also reward 'good' (compliant) behavior, rather than taking it as given. As Table 1 reveals, such measures can take two forms. On the one hand, they can prevent citizens from entering the undeclared economy in the first place such as by simplifying compliance and providing incentives to operate in the declared economy. On the other hand, they can seek to cure those already operating in the undeclared economy by providing either supply-side incentives for them to operate in the declared economy (e.g., amnesties) or demand-side incentives to stop people purchasing goods and services in the undeclared economy (e.g., target direct taxes, service voucher schemes). In
Croatia, such direct controls to increase the benefits of declared work have been so far hardly used (see Baric and Williams 2013; Franic and Williams 2014).

\section{Indirect Controls Approach}

One problem with using direct controls to alter the cost/benefit ratio is that this is expensive (Alm 2011). An alternative approach is to engender a commitment in citizens to be compliant so that they self-regulate. To do this, indirect controls are used that seek to improve the psychological contract between the state and citizens (Alm and Torgler 2011; Weigel, Hessin, and Elffers 1987; Wenzel 2002). The goal is to engender voluntary commitment to compliant behavior rather than force citizens to comply using threats, harassment and/or bribes (Kirchler 2007; Torgler 2007, 2011).

To understand the tools used to achieve this, it is first necessary to recognize that there exists an institutional asymmetry between the laws, codes and regulations of formal institutions and the norms, beliefs and values of informal institutions (Efendic, Pugh and Adnett 2011a,b; Helmke and Levitsky 2004; North 1990; Webb et al 2009). Undeclared work occurs when the norms, values and beliefs (informal institutions) differ to the laws and regulations (formal institutions), resulting in what formal institutions deem to be illegal 
activities being seen as socially legitimate in terms of the norms, values and beliefs of entrepreneurs (Williams and Shahid 2015). To tackle undeclared work therefore, there is a need to reduce this asymmetry between the formal and informal institutions. This can be achieved either by changing the informal institutions and/or the formal institutions.

To change informal institutions (i.e., the norms, values and beliefs of citizens regarding compliance) so that these are in symmetry with the formal institutions, governments can either seek to improve tax knowledge, use awareness raising campaigns about the costs of undeclared work and benefits of declared, or use normative appeals. However, in societies in which there is a lack of trust in government, such as due to public sector corruption (European Commission 2014), it is also the case that formal institutions need to change. This requires improvements in the perception amongst citizens that there is tax fairness, procedural justice and redistributive justice (Braithwaite and Reinhart 2000, Murphy 2005; Taylor 2005; Tyler 1997; Wenzel 2002).

\section{Evaluating direct versus indirect control approaches}

Although there is now a considerable literature which evaluates the validity of facets of one or other of these approaches for tackling undeclared work, there has been until now a lack of research which evaluates these approaches in a South-East European context. Beyond South-Eastern Europe however, a large and expanding body of scholarship reveals that increasing penalties or the probability of detection may not lead to greater compliance (Feld and Frey 2002; Murphy 2005; Varma and Doob 1998; Shaw, Slemrod and Whiting 2008; Webley and Halstead 1986). Instead, it raises non-compliance, not least due to a breakdown of trust between the state and its citizens (Ayres and Braithwaite 1992; Murphy and Harris 2007; Tyler et al. 2007). Indeed, the most telling critique of the use of deterrents is the suggestion that many voluntarily comply even when the level of penalties and risks of detection would suggest that they should not if they were truly rational economic actors (Murphy 2008).

Similarly, and in relation to indirect controls, there is now a large body of scholarship that evaluates the effectiveness of pursuing changes in informal and formal institutions (Braithwaite and Reinhart 2000, Gangl et al. 2013; Kirchgässner 2010, 2011; McGee 2005, 2008; Molero and Pujol 2012; Murphy 2005; Taylor 2005; Tyler 1997, Wenzel 2002). Studies have for example examined the effectiveness of awarenessraising campaigns to change attitudes towards compliance. As a UK study reveals, advertising campaigns run by the UK tax office have provided a return of 19:1 on the expenditure of $£ 2$ million, compared with an overall return of 4.5: 1 on the $£ 41$ million a year spent on all its detection and compliance work in 2006-07 (National Audit Office 2008). Similarly, and in the US, Chung and Trivedi (2003) examine the impact of normative appeals on a friendly persuasion group who were required to both generate and read a list of reasons why they should comply fully and compared with a control group not asked to do so. The participants in the friendly persuasion groups report higher earnings than the control group.

There have also been studies which reveal that improving procedural justice, which refers to whether citizens perceive the government to treat them in a respectful, impartial and responsible manner, significantly improves compliance (Braithwaite and Reinhart 2000, Gangl et al. 2013; Murphy 2005; Taylor 2005; Tyler 1997, Wenzel 2002). Similar findings have been revealed with respect to developing procedural fairness which refers to the extent to which citizens believe that they are paying their fair share compared with others (Kirchgässner 2010, 2011; McGee 2005, 2008; McGee, Alver and Alver 2008; Molero and Pujol 2012) and in relation to enhancing redistributive justice, which refers to whether citizens believe they receive the goods and services they deserve given the taxes that they pay (Kirchgässner 2010, McGee 2005).

Until now however, few if any studies have evaluated these approaches in a South-East European context. Does the deterrence approach of increasing the penalties and risks of detection reduce the likelihood of participation in undeclared in South-Eastern Europe? And does a commitment to compliant behavior on the part of citizen's result in a reduction in the likelihood of them participating in undeclared work in South-Eastern Europe? Given the lack of evaluation of these policy approaches in South-Eastern Europe, we here begin to fill this gap. To do so, two hypotheses are here evaluated:

Direct controls hypothesis $(\mathrm{H} 1)$ : there is an association between participation in undeclared work and the perceived penalties and risk of detection.

Indirect controls hypothesis $(\mathrm{H} 2)$ : there is an association between participation in undeclared work and the degree of symmetry between formal and informal institutions. 


\section{DATA AND VARIABLES}

\section{Data}

We here evaluate these hypotheses regarding whether firstly increasing the penalties and risks of detection, and secondly, greater symmetry between formal and informal institutions, reduces the likelihood of participation in undeclared work in SouthEastern Europe. To do this, we here report data from 1,000 face-to-face interviews conducted in Croatia during 2013 as part of the Special Eurobarometer No. 402 survey ('Undeclared work in the European Union'). This survey is the first and so far only comprehensive source of data about not only who participates in undeclared work in Croatia but also citizens' views on the penalties and risk of detection, and acceptability of participating in undeclared work (and thus citizens level of commitment to compliance).

To collect this data, a multi-stage random (probability) sampling methodology was used to ensure that on the issues of gender, age, region and locality size, the Croatian national level sample as well as each level of the sample, was representative in proportion to its population size. In every household the 'closest birthday' rule was applied to select respondents, while every subsequent address was determined by the standard 'random route' procedure. The resultant dataset comprises a survey of 1,000 Croatian citizens above 18 years of age. In the face-to-face interviews, participants were firstly asked questions regarding their views on the acceptability of various types of undeclared work and their views on the level of penalties and risks of detection, followed by questions on whether they had purchased from the undeclared economy and finally, whether they had participated in the undeclared economy in the prior 12 months.

\section{Variables}

To evaluate whether firstly increasing the penalties and risks of detection, and secondly, greater symmetry between formal and informal institutions, reduces the likelihood of participation in undeclared work in Croatia, two dependent variables are used. The first examines from the supply-side who participates in undeclared work and is a dummy variable with recorded value 1 for persons who answered 'yes' to the question, 'Have you yourself carried out undeclared work in the last 12 months?'. The second examines from the demand-side who purchases goods and services in the undeclared economy and is again a dummy variable with recorded value 1 for persons who answered 'yes' to the question, 'Have you in the last 12 months acquired any goods or services on an undeclared basis?'.

In order to evaluate whether there is an association between participation in undeclared work and the two types of policy measure, three explanatory variables are used. The first two variables examine the dominant deterrence side of the direct controls approach. On the one hand, and to evaluate whether the perceived risk of detection influences participation, respondents were asked to evaluate the perceived the risk of detection in Croatia. To do this, a categorical variable is used to measure the risk of being detected when engaging in undeclared work with four possible answers; very small, fairly small, fairly high or very high. On the other hand and to evaluate how penalties are associated with participation, they were asked about what they thought were the expected sanctions for those caught conducting undeclared work. For this categorical variable, the three possible answers were: normal tax or social security contributions are due; normal tax or social security contributions are due, plus a fine; and prison.

To evaluate the association between participation in undeclared work and the indirect controls approach meanwhile, the level of institutional symmetry was measured using an interval variable based on participants rating the acceptability of four types of undeclared work using a 10-point Likert scale (1 equals absolutely unacceptable and 10 equals absolutely acceptable). These four types of undeclared work were: an individual is hired by a household for work and he/ she does not declare the payment received to the tax or social security authorities even though it should be declared; a firm is hired by a household for work and it does not declare the payment received to the tax or social security authorities; a firm hires an individual and all or a part of the wages paid to him/her are not officially declared; and someone evades taxes by not declaring or only partially declaring their income. Given the substantial pairwise correlations across these four indicators (ranging between 0.36 and 0.74) and the high Cronbach's alpha of 0.82 , exploratory factor analysis was applied to reduce the dimensionality. The factor analysis indicated the existence of a single factor underlying the respondents' perceptions towards the given noncompliant behaviours, which can thus be labelled as a 'tax morale index'. Overall, each of the four individual indicators contributes significantly to the extracted index, with communalities ranging from 0.42 to 0.80 . To reflect the scale of the four baseline variables, the obtained tax morale index has been transformed to follow the original 10-point Likert scale. Therefore, lower values of the index represent higher tax morale (and thus high institutional 
Table 2 Summary of variables used in the logistic regression modelling

\begin{tabular}{|c|c|c|c|}
\hline Variable name & Description & Values & $\begin{array}{l}\text { Number of } \\
\text { missing values }\end{array}$ \\
\hline $\begin{array}{l}\text { Participation in un- } \\
\text { declared work }\end{array}$ & $\begin{array}{l}\text { A dummy variable indicating whether } \\
\text { a respondent carried out undeclared } \\
\text { work during } 12 \text { months preceding the } \\
\text { survey. }\end{array}$ & $\begin{array}{l}0 \text { - no; } \\
1 \text { - yes }\end{array}$ & 35 \\
\hline $\begin{array}{l}\text { Purchase of unde- } \\
\text { clared goods and } \\
\text { services }\end{array}$ & $\begin{array}{l}\text { A dummy variable indicating whether } \\
\text { a respondent acquired undeclared } \\
\text { goods and/or services during } 12 \\
\text { months preceding the survey. }\end{array}$ & $\begin{array}{l}0 \text { - no; } \\
1 \text { - yes }\end{array}$ & 65 \\
\hline Gender & $\begin{array}{l}\text { A dummy variable for respondent's } \\
\text { gender }\end{array}$ & $\begin{array}{l}0 \text { - male; } \\
1 \text { - female }\end{array}$ & 0 \\
\hline Age & $\begin{array}{l}\text { An interval variable indicating the } \\
\text { exact age of a respondent }\end{array}$ & Values representing exact age & 0 \\
\hline Occupation & $\begin{array}{l}\text { A categorical variable describing work } \\
\text { status of a respondent }\end{array}$ & $\begin{array}{l}1 \text { - unemployed; } \\
2 \text { - self-employed; } \\
3 \text { - dependent employee; } \\
4 \text { - inactive (house persons, students, } \\
\quad \text { etc.); } \\
5 \text { - retired }\end{array}$ & 0 \\
\hline Financial situation & $\begin{array}{l}\text { A categorical variable indicating how } \\
\text { often a respondent finds herself/him- } \\
\text { self in difficulty to pay bills }\end{array}$ & $\begin{array}{l}1 \text { - most of the time; } \\
2 \text { - from time to time; } \\
3 \text { - almost never/never }\end{array}$ & 14 \\
\hline Type of community & $\begin{array}{l}\text { A dummy variable denoting whether a } \\
\text { respondent lives in rural or urban area }\end{array}$ & $\begin{array}{l}0 \text { - rural area or village; } \\
1 \text { - urban area }\end{array}$ & 0 \\
\hline Region & $\begin{array}{l}\text { A categorical variable for a region of } \\
\text { residence }\end{array}$ & $\begin{array}{l}1 \text { - Zagreb and surrounding; } \\
2 \text { - North Croatia; } \\
3 \text { - Slavonia; } \\
4 \text { - Lika and Banovina; } \\
5 \text { - Istra, Rijeka and Gorski Kotar; } \\
6 \text { - Dalmatia }\end{array}$ & 0 \\
\hline Detection risk & $\begin{array}{l}\text { A categorical variable for perceived risk } \\
\text { of being detected when engaged in } \\
\text { unregistered activities }\end{array}$ & $\begin{array}{l}1 \text { - very small; } \\
2 \text { - fairy small; } \\
3 \text { - fairy high; } \\
4 \text { - very high }\end{array}$ & 80 \\
\hline Expected sanctions & $\begin{array}{l}\text { A categorical variable measuring } \\
\text { anticipated penalties when caught in } \\
\text { carrying out unregistered activities }\end{array}$ & $\begin{array}{l}1 \text { - normal tax or social security con- } \\
\text { tributions due; } \\
2 \text { - normal tax or social security con- } \\
\text { tributions due, plus a fine; } \\
3 \text { - prison }\end{array}$ & 285 \\
\hline Tax morale & $\begin{array}{l}\text { An interval variable measuring re- } \\
\text { spondents tax morale }\end{array}$ & $\begin{array}{l}\text { ' } 1 \text { ' denotes the highest level of tax } \\
\text { morale and ' } 10 \text { ' the lowest level }\end{array}$ & 14 \\
\hline
\end{tabular}

Source: Authors' own work based on the Special Eurobarometer 402/Wave EB79.2 
symmetry and greater commitment to being compliant), and vice versa.

To control for the demographic and socio-economic characteristics of respondents, we also include a set of categorical and interval covariates, namely gender, age, occupation, financial situation, type of community (urban or rural) and region of residence, which previous studies reveal influence the level of undeclared work (Alm and Torgler 2011; Williams and Martinez 2014a). The full list and detailed description of all variables used in the logistic models is given in Table 2.

Given that there were a considerable number of missing values with respect to the variables of interest, a multiple imputation technique has been used to address this issue (Royston 2004; Rubin 1987; Schafer \& Graham 2002). Fifty imputations were simulated through a system of chained equations for every missing value. In addition, population weights are applied to correct for over- and under-representation in the sample.

\section{FINDINGS}

To determine whether there is a significant association between participation in undeclared work and these direct and indirect controls, when other characteristics are taken into account and held constant, Table 3 reports the results of two logistic regression analyses of both supply-side participation in undeclared work and the demand-side purchase of goods and services in the undeclared economy.

Starting with whether there is an association between participation in undeclared work and the use of the direct controls, we found no significant impact of the perceived risk of detection on participation in undeclared work, when other variables are held constant. In other words, there is not enough evidence supporting hypothesis 1 . It is not the case that when respondents view there to be a high risk of detection, this is related to lower levels of engagement in undeclared work. Similarly, we found no significant association between participation in undeclared work and the perceived level of sanctions. As such, when respondents perceive the level of sanctions to be high (e.g., prison), this does not imply lower levels of participation in undeclared work. The same is concluded when examining the demand-side. There is not only no significant link between the expected sanctions and the propensity to purchase undeclared goods and services, when other variables are held constant, but the only time that detection risk matters for the decision to purchase undeclared goods and services is when this risk is very high. On the whole therefore, the direct controls of increasing the level of punishments and risk of detection seem not to be significant factors influencing participation in undeclared work. The tentative intimation is that increasing the sanctions and risk of detection will have little impact on participation in undeclared work in Croatia.

Is there however, and as hypothesis 2 asserts, an association between participation in undeclared work and higher tax morale (and thus commitment to compliance)? If so, then this suggests that indirect controls that seek to improve tax morale may well be an effective means of tackling undeclared work. The finding of Table 3 is that this is the case. Tax morale is strongly associated with the propensity to participate in undeclared work not only on the supply-side but also the demand-side. More precisely, a unit decrease in tax morale increases the odds of working undeclared by $58.5 \%$ and the odds of buying undeclared goods and services by $16.9 \%$, holding other variables constant. Put simply, where there is greater commitment to compliance, self-regulation occurs and the propensity to participate in undeclared work is lower. Individuals with a higher tax morale are significantly less likely to work on undeclared basis and also significantly less likely to purchase goods and services in the undeclared economy.

The outcome of these logistic regression analyses therefore, is that little or no association is found between the likelihood of participating in undeclared work either on the supply- or demand-side and the level of punishments and risk of detection, but a strong association is identified with the level of tax morality. The suggestion, therefore, is that policy interventions which seek to increase the level of punishments and risk of detection will have little influence on participation but policy interventions which seek to improve tax morality may well reduce participation.

To whom, therefore, should such indirect controls that seek to improve tax morality be targeted? Table 3 provides some clues since the analysis of the other variables displays which groups have a greater propensity to participate in undeclared work. This reveals that so far as the supply-side is concerned, the groups significantly more likely to participate in undeclared work are men, younger age groups, those who most of the time witness difficulties paying household bills, and those living in urban areas, especially in the capital and surrounding region. These signal the groups therefore, that might be targeted by indirect controls seeking to reduce participation in undeclared work by improving tax morality. On the demand-side however, no occupational, gender, economic and regional variations are found and only a weak significance with age, with younger age groups displaying a greater 
Table 3 Determinants of undeclared work in Croatia, odds ratios

\begin{tabular}{|c|c|c|}
\hline Variables & $\begin{array}{l}\text { Participation in } \\
\text { undeclared work }\end{array}$ & $\begin{array}{l}\text { Purchase of undeclared } \\
\text { goods and services }\end{array}$ \\
\hline \multicolumn{3}{|l|}{ Detection risk (RC: Very small) } \\
\hline - Fairly small & $1.839(0.872)$ & $0.939(0.211)$ \\
\hline - Fairly high & $0.773(0.448)$ & $0.724(0.193)$ \\
\hline - Very high & $0.754(0.844)$ & $0.382 *(0.159)$ \\
\hline \multicolumn{3}{|c|}{ Expected sanctions (RC: Tax or social security contributions) } \\
\hline - Tax or social security contributions plus a fine & $2.428(1.276)$ & $1.494(0.337)$ \\
\hline - Prison & $3.152(2.641)$ & $1.227(0.680)$ \\
\hline Tax morale & $1.588^{* * *}(0.179)$ & $1.169^{* *}(0.062)$ \\
\hline Female & $0.221^{* * *}(0.089)$ & $1.112(0.202)$ \\
\hline Age & $0.976^{*}(0.013)$ & $0.985^{*}(0.007)$ \\
\hline \multicolumn{3}{|l|}{ Occupation (RC: Unemployed ) } \\
\hline - Self-employed & $0.842(0.641)$ & $2.215(1.150)$ \\
\hline - Employed & $0.884(0.434)$ & $1.638(0.467)$ \\
\hline - Inactive (house persons, students, etc.) & $0.373(0.247)$ & $0.963(0.344)$ \\
\hline - Retired & $0.546(0.381)$ & $1.521(0.559)$ \\
\hline \multicolumn{3}{|l|}{ Financial problems (RC: Most of the time) } \\
\hline - From time to time & $0.233^{* * *}(0.106)$ & $1.223(0.307)$ \\
\hline - Almost never/never & $0.285^{* *}(0.127)$ & $1.153(0.286)$ \\
\hline Urban area & $0.184^{* * *}(0.075)$ & $1.305(0.268)$ \\
\hline \multicolumn{3}{|l|}{ Region (RC: Northwest) } \\
\hline - North Croatia & $0.027^{* * *}(0.030)$ & $0.921(0.280)$ \\
\hline - Slavonia & $0.293^{*}(0.159)$ & $0.888(0.263)$ \\
\hline - Lika and Banovina & $0.101 *(0.107)$ & $0.530(0.244)$ \\
\hline - Istra, Rijeka and Gorski Kotar & $0.615(0.365)$ & $0.741(0.226)$ \\
\hline - Dalmatia & $0.311 *(0.169)$ & $1.214(0.332)$ \\
\hline Cons & $4.142(4.989)$ & $0.126^{* *}(0.083)$ \\
\hline Number of observations & 1,000 & 1,000 \\
\hline Number of imputations & 50 & 50 \\
\hline Prob $>\mathrm{F}$ & 0.000 & 0.003 \\
\hline Pseudo R2 & 0.327 & 0.051 \\
\hline Area under ROC & 0.902 & 0.656 \\
\hline
\end{tabular}

Significance: ${ }^{*} \mathrm{p}<0.05,{ }^{* *} \mathrm{p}<0.01,{ }^{* *} \mathrm{p}<0.001$, (standard errors in parentheses)

Notes: 1) Estimates based on multiple imputation technique with 50 imputations

2) Since tax morale is given on an inverse scale, positive coefficients indicate that lower tax morale entails higher likelihood to participate in the unregistered economy

Source: Authors' calculations based on the Special Eurobarometer 402/Wave EB79.2

propensity to purchase goods and services in the undeclared economy.

Given this significant association between tax morality and participation in undeclared work, Figure 1 explores the predicted probabilities of a 'representative' Croatian citizen of different ages participating in undeclared work according to their level of tax morality. Here, a 'representative' Croatian citizen is derived by taking the mean and modal values of the remaining independent variables. As such, the representative citizen is an unemployed woman who lives in an urban area of Slavonia, faces financial problems from time to time, perceives the risk of being detected as fairly small and expects to pay a financial fine 
alongside the tax or social security contributions due when detected participating in the undeclared economy. For simplicity, we present the figures for four representative Croatian citizens aged 24, 25, 50 and 62.

As Figure 1 reveals, the finding is that the propensity of the representative Croatian citizen to supply undeclared work ranges from slightly above 0 per cent for those with the strongest tax morale to almost 40 per cent for those with the lowest tax morale. While there are no significant differences in the predicted probability of participation for those with high tax morale across age groups, significant discrepancies are noticeable across age groups as tax morale worsens. For instance, less than 20 per cent of representative citizens aged 62 who find participating in undeclared work absolutely acceptable are likely to work undeclared, but 30 per cent for those aged 35 and 37 per cent for those aged 24 years old. The important point nevertheless, and leaving aside the age differences, is that the predicted probability of participating in undeclared work for the representative Croatian citizen significantly rises as tax morality worsens.

This is also the case with purchasing undeclared goods and services. The predicted probability of a representative Croatian citizen purchasing goods and services in the undeclared economy ranges from around 20 per cent for those with the highest tax morale to around 50 per cent for those with the lowest tax morale. There is a relatively constant difference across age categories at all levels of tax morality. The predicted probability for the representative citizen aged 62 ranges from 15 per cent to 40 per cent depending on their level of tax morality, whilst it ranges from 23 per cent to 55 per cent for those aged 24, indicating the extent to which younger age groups display a greater propensity to purchase undeclared goods and services. The high share of citizens with even strong tax morale who purchase undeclared goods and services is not surprising however, given the prevalent culture of undeclared exchange in Croatian society (see Franic and Williams 2014; Rubić 2013).

Does the tax morale of a citizen have an influence on the propensity to participate in undeclared work however, even when a citizen feels heavily deterred by the level of punishments and risk of detection? To examine this, Figure 2 graphically represents the predicted probability of participation for an individual who perceives the risk of being detected as very high and expects imprisonment in the case of detection, and this individual has the characteristics of those most prone to engagement in undeclared work, namely they are a self-employed male living in the capital who regularly struggles to pay his bills.

Figure 1 Predicted probability of participation in undeclared economy of a 'representative' Croatian citizen: by tax morality and age

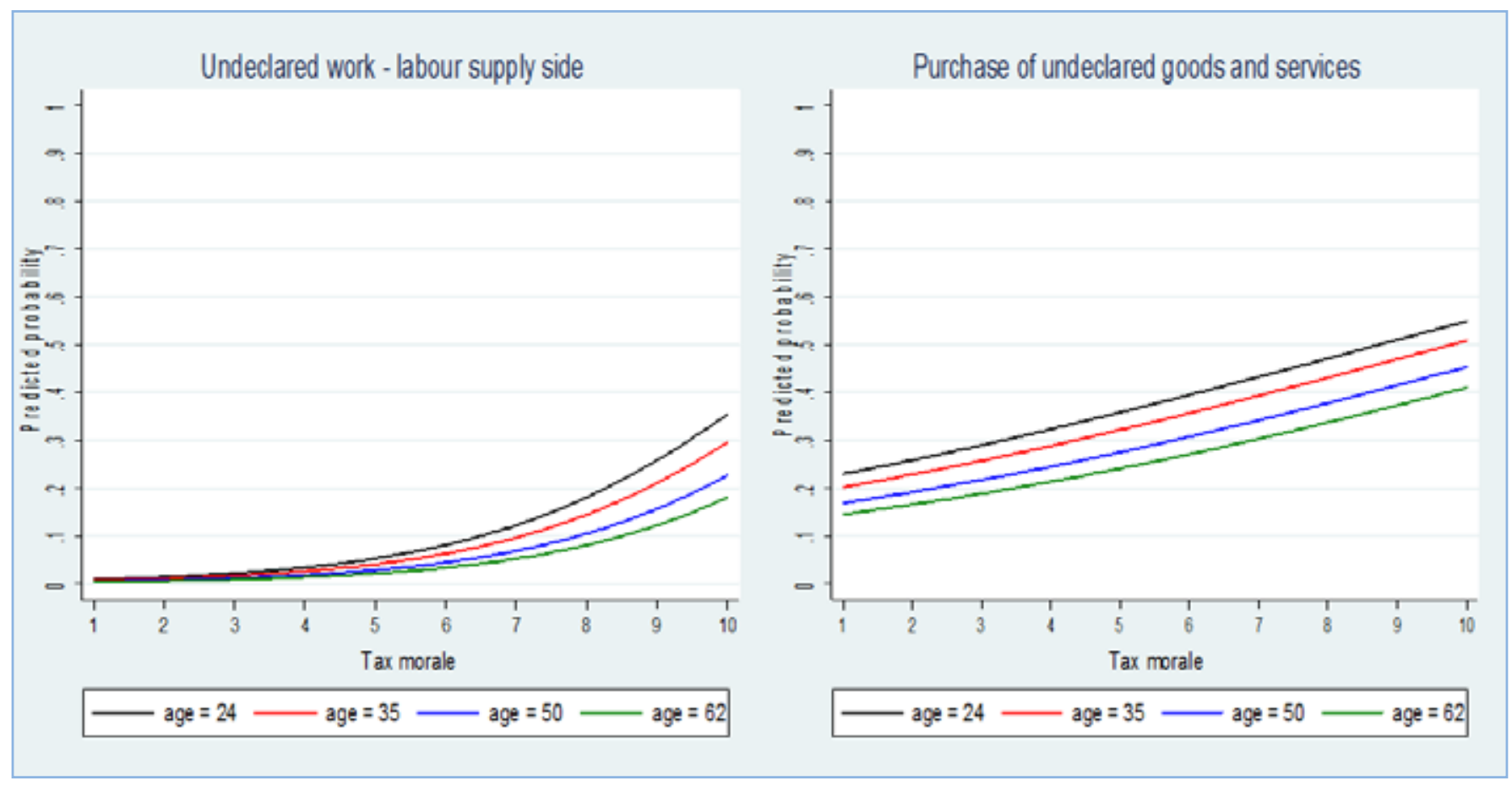

Notes: 1) Tax morale is measured on the scale from 1 to 10 , with value 1 indicating completely unacceptable and 10 absolutely acceptable. Therefore, higher levels mean lower tax morale.

Source: Authors' calculation based on the Special Eurobarometer 402/Wave EB79.2 
Figure 2 Predicted probability of participation in undeclared work of a 'fearful' Croatian prone to undeclared work: by tax morality and age

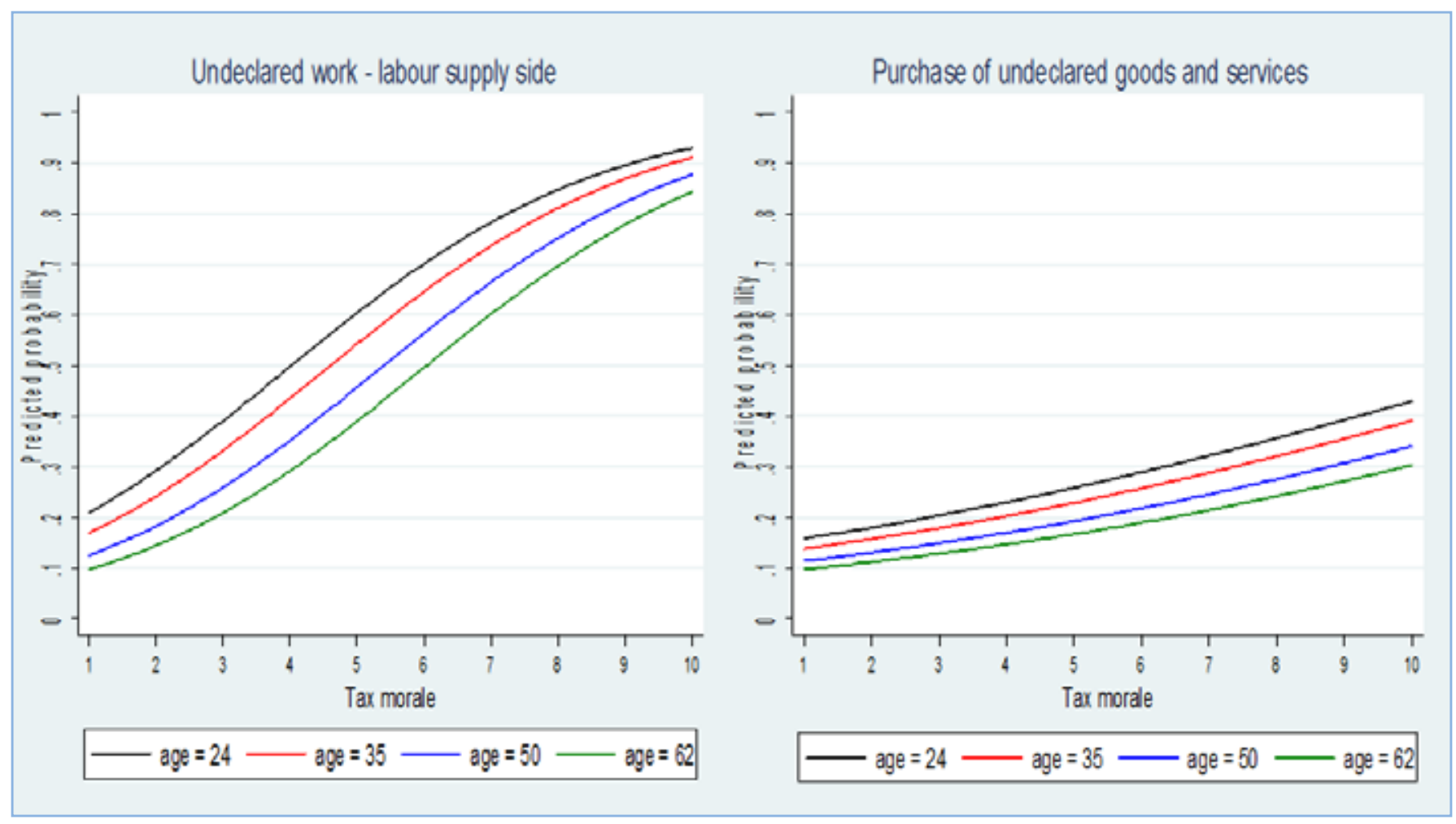

Notes: 1) Tax morale is measured on the scale from 1 to 10 , with value 1 indicating completely unacceptable and 10 absolutely acceptable. Therefore, higher levels mean lower tax morale.

Source: Authors' calculations based on the Special Eurobarometer 402/Wave EB79.2

As Figure 2 reveals, tax morale still plays a significant role in determining the probability of participation in undeclared work, even when examining the 'fearful' Croatian prone to undeclared work who believes that the risk of detection is very high and that prison will result if caught. Analysing the supply-side, this fearful citizen prone to undeclared work has around a 15 per cent probability of supplying undeclared work when they have the highest level of tax morality but around an 85 per cent probability when they hold the lowest level of tax morality. Tax morale therefore, still plays a significant role in determining the probability of participation. As before moreover, the predicted propensity for participation varies by age, with the probability of supplying undeclared work ranging from 84 per cent for those aged 62 years old to 92 per cent for those aged 24 years old with the lowest level of tax morality. On the demand-side, the predicted probabilities of this fearful citizen prone to undeclared work purchasing undeclared goods and services, although lower for the representative Croatian citizen, is again heavily influenced by their level of tax morality. Those with the highest level of tax morality have around a 12 per cent probability of purchasing undeclared goods and services compared with predicted probability of some 35 per cent for those with the lowest level of tax morality.

\section{DISCUSSION}

This paper has sought to evaluate the validity of both the dominant direct controls approach, which seeks to deter engagement in undeclared work by increasing the penalties and risk of detection, and the emergent indirect controls approach which seeks to encourage greater self-regulation and a culture of commitment to compliance. To do this, it has reported evidence from 1,000 face-to-face interviews conducted in Croatia during 2013. A logistic regression analysis reveals no significant association between participation in undeclared work and the perceived level of penalties and risk of detection, but a strong association between participation in undeclared work and the level of tax morality. The intimation is therefore that policy interventions which seek to increase the level of punishments and risk of detection will have little influence on participation but policy interventions which seek to improve tax morality may well reduce participation. In other words, indirect controls 
that seek to engender commitment to compliance appear a potentially effective tool for reducing participation. Here, in consequence, we discuss the theoretical and policy implications of these findings.

Theoretically, this paper provides evidence to support the emergent explanation for undeclared work grounded in institutional theory which suggests that undeclared work can be explained as resulting from a violation of the social contract that exists between the state and its citizens (Webb et al. 2009; Williams, Franic and Dzhekova 2014; Williams and Horodnic 2015a,b). Undeclared work in other words, arises when the norms, values and beliefs of citizens (civic morality) do not align with the codified laws and regulations of a society's formal institutions (state morality). The wider is the gap between state morality and civic morality (and thus the lower is the level of tax morality), the greater is the likelihood of participation in undeclared work. As such, this analysis provides a quantitative reinforcement for a burgeoning view that participation in undeclared work in Croatia is in large part due to the lack of alignment of civic morality with state morality (Čučković 2002; Rubić 2013; Šundalić 1999). Whether similar findings are identified in other SouthEast European countries now needs to be investigated, perhaps using the same Eurobarometer data-set.

Turning to the policy implications, the finding is that direct controls of higher penalties and the risk of detection have no significant influence on the decision to participate in undeclared work, but that the indirect control approach of engendering a commitment to compliance is strongly associated with participation. This suggests the need for a change in policy approach. The current focus upon increasing penalties and the risk of detection in order to tackle the undeclared economy needs to be replaced. Instead, what is required is a focus upon engendering a commitment to compliance by improving the tax morality of the population.

Firstly, this requires attention to be given to changing the norms, values and beliefs of the informal institutions in Croatia, so as to align them with the codified laws and regulations of the formal institutions. This necessitates the introduction of tax education so that citizens' understand what taxation is for and what government services are provided as a result of taxes collected. One way of doing this might be to provide a letter to all tax-payers which details where their taxes are spent and what services they receive in return. More directly, it could also include signs being put up in schools, doctor's surgeries and hospitals informing them that their taxes paid for these services. Table 3 reveals furthermore, that such tax education campaigns might well focus upon men, younger age groups, those who most of the time witness difficulties paying household bills, and those living in urban areas, especially in the capital and surrounding region, since these are the groups displaying a greater propensity to engage in undeclared work.

It is little use simply seeking to change informal institutions however, without also changing formal institutions. In South-East European countries such as Croatia, the norms and values of informal institutions will remain at odds with those of the formal institutions until the formal institutions change. Until now, the direct controls approach which uses penalties and detection has been a 'cops and robbers' approach which views citizens as criminals and is founded upon a low-trust, adversarial and low-commitment view of citizens. The shift towards an indirect controls approach however, necessitates the introduction of a 'customer service-orientated' approach founded upon a high trust high commitment view of citizens. To bring this to fruition, at least three changes are required in formal institutions so that citizens have greater trust and commitment in government.

Firstly, procedural justice must be improved, which means the authorities treating citizens in a respectful, impartial and responsible manner (Murphy, 2005). Secondly, procedural fairness must be improved which means citizens believing that they pay their fair share compared with others (Molero and Pujol, 2012) and third and finally, redistributive justice requires improvement which means citizens believing that they receive the goods and services they deserve based on the taxes they pay (Kirchgässner, 2010).

\section{CONCLUSIONS}

This paper displays the need for a new policy approach towards undeclared work in Croatia. It has revealed that there is no association between participation in undeclared work and the perceived level of penalties and risk of detection. However, there is a strong association between engagement in undeclared work and the level of tax morality, suggesting that efforts are required to engender a culture of commitment to compliance. Nevertheless, this paper has limitations. The major limitation is that although the quantitative analysis displays the importance of tax morality, it has not been able to identify the reasons for the low tax morality of the Croatian population. Future research is therefore required to identify these reasons. This will then enable an identification of the policy approaches required to engender commitment to compliance.

In sum, this paper has evaluated the use of direct 
and indirect controls for tackling undeclared work. Whether similar findings are revealed in other SouthEast European countries now requires evaluation. If this paper inspires such evaluations, it will have achieved one of its intentions. However, if it also encourages South-East European governments to shift towards an indirect controls approach and to implement the policy measures required to do so, rather than persist with detection and punishment, then this paper will have achieved its broader intention.

\section{REFERENCES}

Aliyev, H. 2015. Post-Soviet informality: towards theorybuilding. International Journal of Sociology and Social Policy 35 (3-4): 121-42.

Allingham, M. and Sandmo, A. 1972. Income tax evasion: a theoretical analysis. Journal of Public Economics 1: 323-338.

Alm, J. 2011. Designing alternative strategies to reduce tax evasion. In Tax Evasion and the Shadow Economy, edited by M. Pickhardt and A. Prinz, 13-32. Cheltenham: Edward Elgar.

Alm, J. and Torgler, B. 2011. Do ethics matter? tax compliance and morality. Journal of Business Ethics 101: 635-51.

Andrews, D., Caldera Sanchez, A. and Johansson, A. 2011. Towards a Better Understanding of the Informal Economy. Paris: OECD Economics Department Working Paper no. 873, OECD.

Ayres, I. and Braithwaite, J. 1992. Responsive Regulation: transcending the deregulation debate. New York: Oxford University Press.

Baric, M. and Williams, C.C. 2013. Tackling the undeclared economy in Croatia. South-Eastern Europe Journal of Economics 1: 7-36.

Boels, D. 2014. It's better than stealing: informal street selling in Brussels. International Journal of Sociology and Social Policy 34 (9/10): 670-693.

Braithwaite, V. and Reinhart, M. 2000 The Taxpayers' Charter: does the Australian Tax Office comply and who benefits. Canberra: Centre for Tax System Integrity Working Paper no.1, Australian National University.

Čučković, N. 2002. Siva ekonomija i proces privatizacije u Hrvatskoj, 1997-2001 [The grey economy and the privatisation process in Croatia, 1997-2001]. Financijska teorija ipraksa 26: 245-271.

Efendic, A., Pugh, G. and Adnett, N. 2011a. Confidence in formal institutions and reliance on informal institutions in Bosnia and Herzegovina: an empirical investigation using survey data. Economics of Transition 19 (3): 521-40.

Efendic, A., Pugh, G. and Adnett, N. 2011b. Institutions and economic performance: a meta-regression analysis. European Journal of Political Economy 27: 586-99.
European Commission. 2007. Stepping up the Fight against Undeclared Work. Brussels: European Commission.

European Commission. 2014b. Decision of the European Parliament and of the Council on establishing a European platform to enhance cooperation in the prevention and deterrence of undeclared work COM(2014) 221 final. Brussels: European Commission.

Feld, L. and Larsen, C. 2012. Undeclared Work, Deterrence and Social Norms: the case of Germany. Berlin: Springer Verlag.

Feld, L.P. and Frey, B.S. 2007. Tax Compliance as the Result of a Psychological Tax Contract: The Role of Incentives and Responsive Regulation. Law and Policy 29: 102-120.

Franic, J. and Williams, C.C. 2014. The Undeclared Economy in Croatia. A Baseline Assessment. GREY Working Paper No. 2, Sheffield: Sheffield University Management School.

Galić Nagyszombaty, A. 2012. Unofficial economy in Croatia: Estimation methods and results. Ekonomski pregled 63: 734-762.

Gangl, K., Muehlbacher, S., de Groot, M., Goslinga, S., Hofmann, E., Kogler, C., Antonides, G. and Kirchler, E. 2013. 'How can I help you?': perceived service orientation of tax authorities and tax compliance. Public Finance Analysis 69 (4): 487-510.

Gasparaeniene, L., Kartasova, J. and Remeikiene, R. 2014. Evaluation of shadow economy emergence and development factors in service sector: Greek case. Academic Journal of Interdisciplinary Studies 3: 139-145.

Hasseldine, J. and Li, Z. 1999. More tax evasion research required in new millennium. Crime, Law and Social Change 31 (1): 91-104.

Helmke, G. and Levitsky, S. 2004. Informal institutions and comparative politics: a research agenda. Perspectives on Politics 2: 725-740.

Hudson, J, Williams, C.C., Orviska, M. and Nadin, S. 2012. Evaluating the impact of the informal economy on businesses in South East Europe: some lessons from the 2009 World Bank Enterprise Survey. The South-East European Journal of Economics and Business 7: 99-110.

ILO. 2014. Transitioning from the informal to the formal economy. Report V (1), International Labour Conference, 103rd Session (2014). Geneva: ILO.

Job, J., Stout, A. and Smith, R. 2007. Culture change in three taxation administrations: from command and control to responsive regulation. Law and Policy 29 (1): 84-101.

Kirchgässner, G. 2010. Tax Morale, Tax Evasion and the Shadow Economy. St Gallen: Discussion Paper no 201017, Department of Economics, University of St. Gallen, St. Gallen, Switzerland.

Kirchgässner, G. 2011. Tax morale, tax evasion and the shadow economy. In Handbook of the Shadow Economy, edited by F. Schneider, 347-74. Cheltenham: Edward Elgar.

Kirchler, E. 2007. The Economic Psychology of Tax Behaviour. Cambridge: Cambridge University Press. 
Klarić, V. 2011. Estimating the size of non-observed economy in Croatia using the MIMIC approach. Financial Theory and Practice 35: 59-90.

McGee, R.W. 2005. The ethics of tax evasion: a survey of international business academics. Paper presented at the $60^{\text {th }}$ International Atlantic Economic Conference, New York, October 6-9.

McGee, R.W. 2008. Taxation and Public Finance in Transition and Developing Countries. New York: Springer.

McGee, R.W., Alver, J. and Alver, L. 2008. The ethics of tax evasion: a survey of Estonian Opinion. In Taxation and Public Finance in Transition and Developing Countries, edited by R.W. McGee, 119-36. Berlin: Springer.

Ministry of Labour and Pension System. 2014. 2014: godina borbeprotivradanacrno[2014-theyearofthefightagainst undeclared work]. Retrieved 17.4.2014, from http:// www.mrms.hr/2014-godina-borbe-protiv-rada-na-crno/

Molero, J.C. and Pujol, F. 2012. Walking inside the potential tax evader's mind: tax morale does matter. Journal of Business Ethics 105: 151-162.

Murphy, K. 2005. Regulating more effectively: the relationship between procedural justice, legitimacy and tax non-compliance. Journal of Law and Society 32: 562-589.

Murphy, K. 2008. Enforcing tax compliance: to punish or persuade? Economic Analysis and Policy 38 (1): 113-35.

Murphy, K. and Harris, N. 2007. Shaming, shame and recidivism: a test of re-integrative shaming theory in the white-collar crime context. British Journal of Criminology 47: 900-917.

National Audit Office. 2008. Tackling the Hidden Economy. London: National Audit Office.

North, D.C. 1990. Institutions, Institutional Change and Economic Performance. Cambridge: Cambridge University Press.

OECD. 2008. OECD Employment Outlook. Paris: OECD.

OECD. 2012. Reducing Opportunities for Tax Non-Compliance in the Underground Economy. Paris: OECD.

Official Gazette. 2011. Prohibition and Prevention of Unregistered Activities Act. 61/11.

Ott, K. 2002. Neslužbeno gospodarstvo u Republici Hrvatskoj [Unofficial economy in Croatia. Financijska teorija i praksa, 26: 1-30.

Pedersen, S. 2003. The Shadow Economy in Germany, Great Britain and Scandinavia: a measurement based on questionnaire surveys. Copenhagen: The Rockwool Foundation Research Unit.

Polese, A. and Rodgers, P. 2011. Surviving post-socialism: the role of informal economic practices. International Journal of Sociology and Social Policy, 31 (11/12): 612-618.

Remeikiene, R., Gasparaeniene, L. and Kartasova, J. 2014. Country-level determinants of the shadow economy during 2005-2013: the case of Greece. Mediterranean Journal of Social Sciences 5: 454-460.
Richardson, M. and Sawyer, A. 2001. A taxonomy of the t ax compliance literature: further findings, problems and prospects. Australian Tax Forum 16 (2): 137-320.

Royston, P. 2004. Multiple imputation of missing values. The Stata Journal 4(3): 227-241.

Rubić, T. 2013. Afternoon moonlighting - it was a must: the dynamics and paradoxes of the Croatian socialist and post-socialist labor market. Narodna umjetnost 50(1): 121-145.

Rubin, D. B. 1987. Multiple imputation for nonresponse in surveys. New York: Wiley.

Schafer, J. and Graham, J. 2002. Missing data: Our view of the state of the art. Psychological Methods 7 (2): 147-177.

Schneider, F. 2013. Size and development of the shadow economy of 31 European and 5 other OECD countries from 2003 to 2013: a further decline. Retrieved from http://www.econ.jku.at/members/Schneider/files/publications/2013/ShadEcEurope31_Jan2013.pdf (accessed 6 November 2014).

Schneider, F. and Williams, C.C. 2013. The Shadow Economy. London: Institute of Economic Affairs.

Shaw, J., Slemrod, J. and Whiting, J. 2008. Administration and Compliance. London; Institute for Fiscal Studies.

Small Business Council. 2004. Small Business in the Informal Economy: making the transition to the formal economy. London: Small Business Council.

State Inspectorate. 2013a. Inspekcijski nadzori gospodarskih inspektora iz područja prometa roba i usluga, neregistriranih djelatnosti, ugostiteljstva i turizma za razdoblje 1. siječnja - 30. rujna 2013 [Inspections in the fields of trade of goods and services, unregistered activities, catering and tourism for the period 1 January-30 September 2013]. Zagreb: State Inspectorate.

State Inspectorate. 2013b. Izvješće o radu Državnog inspektorata u 2012.godini [State Inspectorate. Annual report 2012]. Zagreb: State Inspectorate.

Šundalić, A. 1999. Privatizacijski novum - obećavajuća ili neizvjesna sudbina većine [Privatisation novelty-a promising or uncertain fate of the majority]. In Privatizacija $i$ javnost [Privatisation and the public], edited by D. Čengić and I. Rogić, 141-60. Zagreb: Institute of Social Sciences Ivo Pilar.

Taylor, N. 2005. Explaining taxpayer noncompliance through reference to taxpayer identities: a social identity perspective. In Size, Causes and Consequences of the Underground Economy: an international perspective, edited by C. Bajada and F. Schneider, 39-54. Aldershot: Ashgate.

Torgler, B. 2007. Tax morale in Central and Eastern European countries. In Tax Evasion, Trust and State Capacities: how good is tax morale in Central and Eastern Europe?, edited by N. Hayoz and S. Hug, 155-86. Bern: Peter Lang.

Torgler, B. 2011. Tax morale and compliance: review of evidence and case studies for Europe. Washington DC: World Bank Policy Research Working Paper 5922, World Bank. 
Tyler, T. 1997. The psychology of legitimacy: a relational perspective $\mathrm{n}$ voluntary deference to authorities. Personality and Social Psychology Review 1 (4): 323-45.

Tyler, T.R., Sherman, L., Strang, H., Barnes, G. and Woods, D. 2007. Reintegrative shaming, procedural justice and recidivism: the engagement of offenders' psychological mechanisms in the Canberra RISE drinking and driving experiment. Law and Society 41 (3): 553-86.

Varma, K. and Doob, A. 1998. Deterring economic crimes: the case of tax evasion. Canadian Journal of Criminology 40: $165-84$.

Webb, J.W., Tihanyi, L., Ireland, R.D. and Sirmon, D.G. 2009. You say illegal, I say legitimate: entrepreneurship in the informal economy. Academy of Management Review 34: 492-510.

Webley, P. and Halstead, S. 1986. Tax evasion on the micro: significant stimulations per expedient experiments. Journal of Interdisciplinary Economics 1: 87-100.

Weigel, R., Hessin, D. and Elffers, H. 1987. Tax evasion research: a critical appraisal and theoretical model. Journal of Economic Psychology 8 (2): 215-35.

Wenzel, M. 2002. The impact of outcome orientation and justice concerns on tax compliance: the role of taxpayers' identity. Journal of Applied Psychology 87: 639-45.

Williams, C.C. 2014a. Confronting the Shadow Economy:evaluating tax compliance and behaviour policies. Cheltenham: Edward Elgar.

Williams, C.C. 2014b. Out of the shadows: a classification of economies by the size and character of their informal sector. Work, Employment and Society 28: 735-753.

Williams, C.C. 2014c. Explaining cross-national variations in the prevalence and character of undeclared employment in the European Union. European Spatial Research and Policy 21 (2): 115-132.

Williams, C.C. and Horodnic, I. 2015a. Rethinking the marginalisation thesis: an evaluation of the socio-spatial variations in undeclared work in the European Union. Employee Relations 37 (1): 48-65.
Williams, C.C. and Horodnic, I. 2015b. Evaluating the prevalence of the undeclared economy in Central and Eastern Europe: an institutional asymmetry perspective. European Journal of Industrial Relations, doi: 10.1177/0143831X14568835

Williams, C.C. and Horodnic, I. 2015c. Explaining the prevalence of illegitimate wage practices in Southern Europe: an institutional analysis. South European Society and Politics, http://dx.doi.org/10.1080/13608746.2015.1013 518

Williams, C.C. and Martinez, A. 2014a. Explaining cross-national variations in tax morality in the European Union: an exploratory analysis. Studies in Transition States and Societies, 6: 5-17.

Williams, C.C. and Martinez-Perez, A. 2014b. Why do consumers purchase goods and services in the informal economy? Journal of Business Research 67(5): 802-806.

Williams, C.C. and Shahid, M. 2015. Informal entrepreneurship and institutional theory: explaining the varying degrees of (in)formalisation of entrepreneurs in Pakistan. Entrepreneurship and Regional Development, http:// dx.doi.org/10.1080/08985626.2014.963889

Williams, C.C., Franic, J. and Dzhekova, R. 2014. Explaining and tackling the undeclared economy in Bulgaria: an institutional asymmetry perspective. The South-East European Journal of Economics and Business 9 (2): 33-45

Williams, C.C., Kedir, A., Fethi, M. and Nadin, S. 2012. Evaluating 'varieties of capitalism' by the extent and nature of the informal economy: the case of South-Eastern Europe. South Eastern Europe Journal of Economics 10: 87-104.

Williams, C.C., Nadin, S., Kedir, A. and Vorley, T. 2013. Evaluating the extent and nature of the informalisation of employment relations in South-East Europe. European Journal of Industrial Relations 19 (2): 91-107. 